BULLETIN Bulletin hispanique

HISPANIQUE Université Michel de Montaigne Bordeaux

$119-2 \mid 2017$

La Égloga renacentista en el Reino de Nápoles

\title{
Ecos de la preceptiva minturniana en la concepción de las églogas de Garcilaso
}

\section{Eugenia Fosalba}

\section{(2) OpenEdition \\ 1 Journals}

\section{Edición electrónica}

URL: http://journals.openedition.org/bulletinhispanique/5126

DOI: 10.4000/bulletinhispanique.5126

ISSN: $1775-3821$

\section{Editor}

Presses universitaires de Bordeaux

\section{Edición impresa}

Fecha de publicación: 1 diciembre 2017

Paginación: 555-572

ISBN: 979-10-300-0218-8

ISSN: 0007-4640

Referencia electrónica

Eugenia Fosalba, «Ecos de la preceptiva minturniana en la concepción de las églogas de Garcilaso», Bulletin hispanique [En línea], 119-2 | 2017, Publicado el 28 diciembre 2020, consultado el 15 enero 2021. URL: http://journals.openedition.org/bulletinhispanique/5126 ; DOI: https://doi.org/10.4000/ bulletinhispanique.5126 


\title{
Ecos de la preceptiva minturniana en la concepción de las églogas de Garcilaso
}

\author{
Eugenia Fosalba \\ Universitat de Girona
}

Après avoir tenté de démontrer (en 2016) les motifs presque exclusivement historiques qui situent la composition du De Poeta d'Antonio Sebastiano Minturno à des dates bien antérieures (1525-1533) à sa publication (1559), l'auteur analyse, dans le présent article, le contexte littéraire dans lequel ce traité, très proche des Prose della volgar lingua (1525) de Bembo, a été écrit, ainsi que sa possible influence sur la conception des églogues de Garcilaso.

Mots-clés: Minturno, De Poeta, Garcilaso de la Vega, églogue.

Tras tratar de demostrar (en 2016) los motivos casi exclusivamente históricos que ubican la composición del De Poeta de Antonio Sebastiano Minturno en fechas muy anteriores (1525-1533) a su publicación (1559), en el presente artículo se estudia el contexto literario en que se escribió dicho tratado, muy próximo a las Prose della volgar lingua (1525) de Bembo, al tiempo que se analizan sus posibles huellas en la concepción de las églogas de Garcilaso.

Palabras clave: Minturno, De Poeta, Garcilaso de la Vega, égloga.

Having in 2016 attempted to demonstrate the almost exclusively historical reasons that situate the composition of Antonio Sebastiano Minturno's 'De Poeta' to dates (1525-1533) far earlier than its actual publication (1559), this current article studies the literary context in which the said treatise was written, very close to Bembo's 'Prose della volgar lingua' (1525), while also analyzing its possible influence on the genesis of Garcilaso's eclogues.

Keywords: Minturno, De Poeta, Garcilaso de la Vega, eclogue. 
Now in his parts, kindes, or species, as you list to tearme them, it is to be noted, that some Poesies have coupled togither two or three kindes, [...] some have mingled matters Heroicall and Pastorall, but that commeth all to one in this question, for it severed they be good, the conjunction cannot be hurtfull. Philip Sidney, Defense of Poesie (1580-1581)

L a obra de Garcilaso que ha llegado a nuestros días es más bien magra: no sabemos si fue toda la que llegó a escribir en castellano, pero a juzgar por lo que se publicó en la imprenta de Carlos Amorós en 1543, se hace evidente que a partir de cierto momento cada poema pertenece a un género neoclásico distinto (la oda, la elegía amorosa, la funeral, la epístola horaciana, tres églogas, cada una de la cuales pertenece a uno de los cauces servianos: mixta, dramática, y casi completamente narrativa), y en estas primeras muestras, de tan admirable perfección, hay a su vez cierta ponderación metapoética (en la epístola, en la elegía, en el complejo diseño estructual de la égloga II, en el conato autobiográfico del cuarto tapiz de la égloga III). No solo eso, en la ejecución de cada nuevo género poético, y muy especialmente en las églogas, el poeta alcanza la cima de su arte gracias a la extraordinaria ductilidad del número, así como a la sutileza y eficacia de la voluptas aurium, como si fuera consciente de que debía dejar a la posteridad los caminos preparados antes de echar a andar, en feliz expresión de Claudio Guillén. Este viraje neoclásico del poemario, meditado a veces en voz alta, pone más de relieve si cabe el influjo teórico que hubo en la concepción misma de esta fundacional parte de la obra de Garcilaso, que difícilmente pudo darse por generación espontánea de la sola imitación de los modelos ${ }^{1}$.

Hace ya años intuí que Minturno, con el que manifiesta una interesante familiaridad en el soneto 24 dedicado a alabar a Maria de Cardona, podía haber influido en él desde esta perspectiva teórica ${ }^{2}$. La convocatoria de este volumen sobre la égloga renacentista en Nápoles me ha vuelto a poner sobre la senda de esa investigación antes solo esbozada: la lectura atenta del De Poeta y el rastreo de los hechos históricos, los personajes a que se alude, y el cotejo con el nutrido epistolario de su autor, parecen confirmar que el tratado, publicado por primera vez en 1559, se compuso en fechas mucho más tempranas: entre

1. Esta publicación se inscribe en el proyecto "Garcilaso en Italia. Estancia en Nápoles» (2016-2019): FFI2015-65093-P. Agradezco a Juan Francisco Alcina su revisión del texto de Minturno, así como sus sabias sugerencias.

2. Eugenia Fosalba, «Implicaciones teóricas del alegorismo autobiográfico en la égloga III de Garcilaso", Studia Aurea. Revista de Literatura Española y Teoría Literaria del Renacimiento y Siglo de Oro, vol. 3, 2009, pp. 39-104. También en Eugenia Fosalba, "El exordio de la Epistola a Boscán: contexto napolitano", Studia Aurea. Revista de Literatura Española y Teoría Literaria del Renacimiento y Siglo de Oro, vol. 5, 2011, pp. 23-47. 
1525 (o antes, fecha de los primeros apuntes), pasando por 1528 (cuando la experiencia de Ischia pudo darle un nuevo impulso e incluso adquirir forma de diálogo socrático), hasta aproximadamente 1533 (cuando se le pudo añadir el libro VI, el más extenso), pocos años después de la muerte de Sannazaro ${ }^{3}$.

Este cambio de perspectiva histórica con respecto al De Poeta no solo interesa por el hecho ya de por sí relevante de que Garcilaso pudo leer una obra hasta ahora considerada muy posterior. Su reubicación en el tiempo nos la redescubre, además, entera, pues le añade significados que antes no tenía. Como si se tratara de una obra desconocida que de pronto ha salido a la luz.

El De Poeta es una preceptiva que en fechas tan tempranas abarca todas las normas retóricas que rodean la creación poética de forma amplia, ambiciosa y comprehensiva. El objeto central de estudio es la poesía, a la que se considera superior a la prosa y a todas las demás artes de la palabra, porque es el océano en que confluyen todas las disciplinas y en el que todas se originan ${ }^{4}$. Pero el centro de atención es el poeta, como anuncia su título, puesto que se trata de entregarle los instrumentos, los recursos y las ideas esenciales para triunfar en su arte, además de ser una de las partes en que se divide el Ars de Horacio, siguiendo modelos griegos. Si la obra ya estaba compuesta a comienzos de los años treinta, como todo parece confirmar, no cabe interpretarla como una síntesis escrita a ritroso, sino que resulta imprescindible reconocer en ella un carácter ejemplar y didáctico, prospectivo: no se puede obviar que, aunque por entonces no se llegara a publicar, se escribió en un momento clave, en plena eclosión de la poesía renacentista docta en vulgar. Minturno se dirige constantemente en ella a sus lectores, jóvenes poetas como él, mientras despliega la clasificación y análisis de todos los géneros poéticos clásicos: el libro II trata la épica, así como la bucólica, esta última formando parte de la primera; el libro $\mathrm{V}$ analiza la lírica como género novedosamente mayor, que comprende la poesía mélica, la satírica, la elegíaca (sobre la que especifica que para algunos es mélica y para otros es épica), las variedades de poesía epigramática, el epitalamio, la silva, la sátira luciliana, el sermo horaciano. No olvida Minturno la poesía dramática, pues dedica un capítulo entero a la tragedia (libro III) y otro a la comedia (libro IV). Es decir, y ello no es cuestión baladí: la reflexión teórica minturniana procede por géneros. Los Rerum vulgarium fragmenta de Petrarca, o sea, sus sonetos y canciones, han sido ya sancionados por Bembo en 1525, y desde esa misma fecha estudiados en profundidad gracias a las lecciones que Minturno ha ofrecido en su quasi academia napolitana a los jóvenes patricios (Scortianus, Cossa, Tethus), que también son a esas alturas del siglo los destinatarios potenciales del De Poeta ${ }^{5}$.

3. La primera parte del presente trabajo está publicada bajo el título de «Tracce di una precoce composizione (ca. 1525-1533) del De Poeta di Minturno. A proposito della sua possibile influenza su Garcilaso de la Vega», Critica letteraria, no 173, 2017, pp. 627-650.

4. «Quam ob rem meo quidem animo poetica est Oceanus omnium disciplinarum, quo illae omnes sic confluunt...» (Antonii Sebastiani Minturni, De Poeta, ad Hectorem Pignatellum, vibonensium Ducem, libri sex, Venetiis, apud Franciscum Rampazetum, 1559, p. 19).

5. Con este artículo ya en prensa Roland Béhar me ha permitido leer un trabajo suyo en 
Por otro lado, Trissino ha publicado en 1529 sus consejos sobre cómo llevar a la práctica el traspaso de los géneros clásicos a la métrica vulgar, bajo el influjo constante del De Vulgari Eloquentia de Dante, que en el mismo año Trissino ofrece a las prensas de Vicenza en su traducción italiana. Ahora, con un De Poeta manuscrito, muy cercano a la versión que se entregó tres decenios después a las prensas venecianas, estamos en el mismo momento en que Bernardo Tasso busca fórmulas estróficas para inaugurar los variados géneros poéticos clásicos en lengua vulgar.

El concepto que tiene Minturno de los géneros poéticos es singular, si bien no desentona en su tiempo. Opina el de Traetto que la épica supera en calidad y antigüedad a todas las demás subespecies de poesía, e incluso considera que está por encima de la tragedia, sin que le tiemble el pulso cuando le lleva la contraria en este punto al estagirita: de compararse ambos géneros, la épica excedería a la poesía trágica, pues la primera tiene oyentes doctos, dignos, se conforma con mostrar el significado con la voz y el gesto; la segunda, en cambio, requiere numerosas ayudas adicionales, dirigidas a una audiencia de hombres rudos y sin refinar ${ }^{6}$.

Hay que reconocer, no obstante, que en esta acendrada defensa de la épica Minturno está muy lejos de hallarse solo: en el Actius de Pontano, publicado en 1507 por Summonte, se dedicaba una extensa parte del diálogo a las cualidades sonoras de la poesía, para cuya ejemplificación se extraía la mayoría de las referencias de la Eneida. En 1527, un tratadista tan influyente como Marco Girolamo Vida acaba de publicar en Roma su De arte poetica, que a su vez ha circulado manuscrita (y citará Ariosto con elogio en su Orlando), en donde, como en el De Poeta, se otorga la superioridad sobre todos los demás poetas al autor de la Eneida. «Sed nullum e numero carmen praestantius omni, / quam quo post divos heroum facta recensent» («De todos los géneros de poesía ninguno es tan excelente, salvo las canciones de los dioses, como aquel en el que el poeta narra los hechos de los héroes», vv. 33-34, 1. I) 7 . Virgilio se erige, en efecto, en el más alto poeta, así como la Eneida constituye el poema más grande de todos los tiempos. Tampoco hay que olvidar aquí las últimas divisiones de la Poetica de Trissino, que se publicaron tan tarde como en 1562, pero cuya primera escritura tuvo lugar en 1529, en los mismos años en que se publicaron las

donde se trata muy pertinentemente acerca de la distancia que impone Minturno entre epigrama y soneto: «The Epigram and Definitions of the sonnet in Sixteenth-Century Spain, from Herrera to Garcilaso: Notes on an Historical Problem», Brief Forms in Medieval and Renaissance Hispanic Literature, edited by Barry Taylor and Alejandro Coroleu, Newcastle upon Tyne, Cambridge Scholars Publishing, 2017, pp. 114-131.

6. "...ita si poesis cum poesi comparetur, epica longe ante tragicam ponatur, cum enim illa eruditiores grauioresque habeat auditores, uerborum gestu ad significandum contenta est; haec eorum conspectu, qui rudiore nequioreque ingenio sunt, ad docendum multa preaeterea requirit», De Poeta, p. 58.

7. Marco Girolamo Vida, De arte poética, ed. y trad. Ralph G. Williams, New York, Columbia University Press, 1976, p. 4. La edición de A. M. Espirito Santo (Univ. de Lisboa, 1990, p. 140) anota para este pasaje los versos del propio estagirita en 1459b 34-37. 
cuatro primeras partes. El noble preceptista de Vicenza, que obtuvo el honor, junto con otros nobles, de sujetar el manto imperial de Carlos V durante su coronación en Bolonia, y de recibir el título de Conde Palatino solo dos años después ${ }^{8}$, formó parte, como estos hechos ponen de relieve, del círculo de protegidos del Emperador al que pertenecían Minturno y el mismo Garcilaso. No sería extraño que hubieran circulado noticias entre esta elite intelectual acerca de las divisiones quinta y sexta trissinianas, durante tantos decenios a la espera de una revisión final que las sacara definitivamente a la luz, lo que solo sucedió cuando habían transcurrido doce ańos de la muerte de su autor, ocurrida en 1550. En la sexta división, Trissino se hacía eco de la preferencia de Aristóteles por la tragedia, para distanciarse inmediatamente de esta opinión al afirmar que la lengua griega había antepuesto durante largos siglos lo heroico de Homero a todos los demás poemas trágicos que siempre se han escrito, de la misma manera que el poema heroico de Virgilio se había antepuesto, por parte de las gentes, a todos los poemas trágicos que se llevaron a cabo antes y después de él. No obstante, tras haber consignado estas opiniones, Trissino aparentaba negarse a tomar partido, al proponer que en ese contencioso cada cual juzgara como mejor le pareciere, acogiéndose «ouero alla opinione di tanto huomo, fondata sopra le sue salde e ottime ragioni, ouero seguiti il giudicio che ha fatto universalmente il mondo»?.

Si bien es cierto que Minturno se manifiesta, con respecto a la categoría del poema épico, en consonancia con los tratadistas de su tiempo, el sistema de géneros que presenta en su poética reviste una complejidad inusitada, no solo por su generosísima amplitud y meticulosidad, sino también porque en él, a menudo, las aguas de los distintos cauces literarios se mezclan: cuando por ejemplo ofrece una definición triple de la materia de la imitación, señala que, en consecuencia, la manera (o mores) también debería ser triple, y recuerda que la tragedia aporta el personaje excelente, la comedia uno moralmente inferior, y que el tercer tipo, que no tiene nombre, cae entre estos dos: Silio Italico y Lucano son, entre los latinos, preeminentes en este género medio. Aduce entonces el ejemplo de Virgilio, porque alcanzó una majestad trágica en maneras heroicas, y al retratar a los pastores descendió a la ligereza cómica,

8. Vid. Bernardo Morsolin, Giangiorgio Trissino; Monografia d'un gentiluomo letterato nel secolo XVI, Vicenza, Tipografia Burato, 1878, pp. 163-173. Véase también Isabel Paraíso (ed.), Giovan Giorgio Trissino, La Poética, Madrid, Arcolibros, 2014, pp. 13-14; Giuseppe Faggin, "Giangiorgio Trissino e l'impero», Atti del Convegno di studi su Giangiorgio Trissino, Vicenza, Accademia Olimpica, 1980, pp. 23-37.

9. Trissino, La Poética, p. 437. Su editora y traductora al castellano, Isabel Paraíso, es quien apunta el dato, hasta ahora inadvertido, acerca de la temprana escritura de las últimas partes de la poética de Trissino: solo hacía falta tener en consideración lo que el propio autor escribe, en el prefacio, acerca del repaso definitivo que dio a las dos últimas partes, consagradas a la tragedia y el poema heroico, que no tuvo tiempo de dedicarle a la obra, pues en 1529 estaba ocupado en 1 a escritura de la Italia liberata da' Goti. Por otro lado, esta confesión encaja con las primeras palabras de la quinta división, como si no hubiese solución de continuidad con la redacción de las anteriores divisiones: "Poiche hauemo detti tutti e modi de l'accordare le rime, e tutte le specie de poemi, che con quelle si sono fatti, sarà bene lasciarle horamai un poco da canto...» (p. 333). 
una variedad que ni los poetas mélicos ni los ditirámbicos rechazaron, pues el lírico Timoteo de Mileto y Filoxeno de Citera introdujeron cíclopes y hombres llamados Pergae (habitantes de la ciudad de Panfilia, al sur de Anatolia) e incluso los poetas trágicos recurrieron a los sátiros para provocar la risa, de la misma forma que Homero no tuvo empacho en descender a veces a lo cómico ${ }^{10}$.

Llegado a este punto, Minturno asegura que no lamenta en absoluto haber dedicado tanto tiempo y esfuerzo al género épico, aunque pese a ello todavía queden algunas cuestiones en el tintero. Pone entonces el acento en que los poemas épicos abarcan un amplio espectro de tonos, en consonancia con los temas humildes y triviales que conciernen a los pastores, pero también con las cuestiones serias, divinas, y las acciones de hombres famosos, además de los temas medios, como los principios de las cosas. En el poema épico hay, así, tres formas de expresión: a la simple la denomina especialmente épica. Aquí el poeta nunca ingiere su propia persona; en cambio, en el poema bucólico introduce a otro, de manera que el poeta no habla, o habla muy poco; y por fin, en el heroico habla a veces y después introduce personajes que hablan ${ }^{11}$. Ello va a servir para volver a demostrar desde esta nueva perspectiva la superioridad del poema heroico: al ser mixto, su cauce resulta el más comprehensivo de todos, un multigénero, capaz de englobarlos a todos, incluso a la tragedia, lo que vuelve a verificar que es superior a ella ${ }^{12}$.

Este extraordinario valor concedido a la épica es el que justifica uno de los aspectos que pueden resultar más chocantes y singulares de la preceptiva de

10. «Tragica, qua praestans personarum genus; comica, qua deterius exprimitur. Tertia, qua tamquam his interiecta, quales sunt hisce temporibus homines, effinguntur, non dum nomen inuenit, sed per eos, qui in illa claruerunt, plane cognosci potest [...]. Neque enim non epici, quique nudos uersus conscribunt, in hac uarietate uersantur. Quippe Virgilius in rebus herois tragicam maiestatem, in pastorum moribus effingendis comicam quodam modo tenuitatem adhibuit. Neque melici, neque dithyrambici ab hac triplici ratione abhorrent. Nam a Timotheo, Philoxenoque Cyclopes, et quos Pergas uocant, inducuntur. Quin ipsi etiam tragici satyros ad risum ciendum introducunt,, De Poeta, p. 108.

11. "Quandoquidem epicum, inquit, genus est, ut arbitror uobis esse perspectum, in quo me non poenitet, et laboris et temporis plurimum impendisse, de illo mihi quidem quae reliqua sunt, ut in medium proferantur, quae pauca sunt. (Cum enim de poemate dicerem, de illo ipso me multa dicentem audire potuistis) haec plane exponam. Ac multorum generum esse, quae carmine hoc describi solent, nemo sane ignorat. Nam in humili et attenuata materia, ut in iis, quae ad pastores attinent, in magna atque graui ut in rebus diuinis, et in his, quas homines praeclare gesserunt. In mediocri, cuiusmodi sunt rerum praecepta, haec ratio versat. Quemadmodum summum illud genus tractandum esset. In Aeneide plane deprehendes. In Bucolicis quod infimum. In Georgicis quod illud, quod iter haec medium locum tenet, quo usi quoque sunt Lucretius, Cicero, Pontanus. Ac tres epicae rationes dicendi cum sint, simplex, quae priuatim epica uocat, cum poeta nunquam ponit personam suam, bucolica, cum aliam adeo induit, ut ipse nibil, aut pauca narret, heroica, qua cum ipse interdum dicat, tum alios, qui loquantur, inducit, quam minime poeticam illam primam haberi uolunt, tam maxime spectare ad poetam reliquas arbitrantun, De Poeta, p. 146.

12. "Atqui tragoedias ex epica poesi efficias conplures, ac tragicas fabulas una id genus actione permultas complectare», De Poeta, p. 151 («Se podrían hacer muchas tragedias de un poema épico y tener una sola acción épica que incluya muchas tramas trágicas»). Sobre la épica como multigénero, véase Rodrigo Cacho, «Volver a un género olvidado: la poesía épica del Siglo de Oro», Criticón, no 115, 2012, pp. 5-10. 
Minturno: el que la bucólica esté comprendida en ella, que ha subdividido en tres subgéneros según la elevación de su asunto: la épica más humilde, como era de esperar, corresponderá a los poemas que tienen como protagonistas a pastores ${ }^{13}$. La justificación de esta conexión genérica se apuntala sobre la creencia de que ambos géneros, épico y bucólico, tienen un antiguo origen común, del que es testimonio el uso en ambos del hexámetro dactílico, y a la vez, si ambos son los primeros géneros poéticos en la historia, es por ser el hexámetro el metro más antiguo ${ }^{14}$; cuando, en verdad, se trata de una creación culta artificiosa, contraria al ritmo natural de la lengua griega ${ }^{15}$. Pero las inconsecuencias no se detienen ahí, porque de pronto, Minturno da otro giro sorprendente y relaciona la bucólica con la comedia (como también harán Trissino, y más tarde, Viperano $)^{16}:$ «Cum autem genus hoc sit plane summissum,

13. Mientras que, por otro lado, el grado más elevado corresponde a los poemas que tratan temas divinos o narran hazañas de hombres conspicuos («in magna atque graui, ut in rebus diuinis, et in his, quas homines praeclare gesserunt»), y el intermedio, a la poesía didáctica ("In mediocri, cuiusmodi sunt rerum praecepta, haec ratio uersaturn), De Poeta, p. 146.

14. "Genus autem et bucolicum et heroicum eo carmine tractatur, merito uetustissimum esse utrunque apparet. Utrunque enim Apollini ueteres, heroicum Pythio, Nomio bucolicum adscripserunt. Cum ille immani uastaque bellua Delphis occisa uictoriam altero cecinisset, altero, dum Admeti armenta pasceret, amores», De Poeta, p. 162. En este sentido, Minturno se inscribe en la tradición renacentista, de la que es uno de los primeros exponentes, que se remonta a los orígenes remotos y divinos de la poesía para cuestionar dos aspectos clave de la historia literaria que, como ha recordado Cesc Esteve, sirven para demostrar la superioridad de la tragedia: «El primero atañe a la formación de los géneros, que el filósofo atribuye a las diferencias de carácter, o las distintas inclinaciones naturales, de los que habían improvisado los primeros versos. Ante las virtudes y los saberes que la tradición asigna a los prisci vates, entre los que se cuentan, conviene recordarlo, Moisés y otros personajes bíblicos, muchos críticos rechazan el presupuesto de que los primeros poetas fueron unos desconocidos que no podían dominar el arte literario y, sobre todo, se niegan a admitir que entre ellos pudieran encontrarse los autores de condición vulgar que, de atender a Aristóteles, habrían inventado el género burlesco que con el tiempo habría dado pie a la comedia [...]. El segundo aspecto afecta al lugar que ocupa la tragedia en la historia literaria. A diferencia de lo que ocurre con la poesía lírica y la épica, la crítica no dispone de testimonios ni motivos que asocien las formas dramáticas con la antigua poesía sagrada [...]. En suma, la crítica construye un discurso histórico sobre la formación y la evolución de los géneros que cuestiona las premisas del relato aristotélico, desarticula su lógica y anula sus efectos y confirma, por fin, la superioridad ética y artística que la tradición otorga a la poesía heroica». La crítica a que Esteve se refiere y reseña es la que viene a continuación de Minturno: es decir, la de Capriano, Castelvetro, Pellegrini, Tasso y Denores. Es decir, que la supremacía de la épica que desarrolla ampliamente Minturno en su De Poeta es la versión que triunfará ampliamente entre los preceptistas renacentistas. Véase Cesc Esteve, «Una teoría incompleta: la idea de la poesía épica en las artes poéticas italianas del siglo XVI», en María José Vega y Lara Vilà (eds.), Teoría de la épica en el siglo XVI (España. Francia, Italia y Portugal), Vigo, Academia del Hispanismo, 2010, esp. pp. 79-81, pp. 63-101.

15. A. Dain, Traité de métrique grecque, París, 1965, p. 54. Citado por María Luisa Picklesimer, «Teoría de la bucólica en el De poetica de Viperano», en Retórica, poética y géneros literarios, Granada, Universidad de Granada, 2004, p. 381.

16. «Ultimamente diremo qualche cosetta della Egloga pastorale, laquale è, dello istesso genere della poesia, che è la Comedia, cioè de i piu bassi, e dei peggiori, e anchora le persone che se introducono in queste, sono piu humili, e piu basse di quelle, percioche si comne la Comedia è di cittadini 
comico similimum est, eoque ab omni exornatione magis remotum, quo humilius. In utroque enim summissae inducuntur personae») ${ }^{17}$. No pretende emparentarlos, como tampoco dar por supuesto que la bucólica es subgénero de la comedia, sino, como aclara Picklesimer, confrontar "dos géneros que tienen algunas cosas en común» ${ }^{18}$. Más adelante se lee un pasaje no menos inesperado cuando Minturno ańade el canto a lo bucólico, por el acompańamiento de la zampońa con que se recitan a veces sus canciones en los teatros ${ }^{19}$. Puede que se trate de una alusión a los recitales teatrales de la églogas virgilianas que atestiguan varios comentaristas, o bien que se esté haciendo alusión a la égloga escénica tan en boga en la literatura vulgar, con el ejemplo del Orfeo de Angelo Poliziano en primera instancia. Como fuere, llama la atención que aquí se mencione el canto como uno de los componentes de un género que se considera épico, cuando en la definición de este tipo de poesía se había especificado su ausencia de carácter mélico ${ }^{20}$.

Hay que admitir que todas estas vacilaciones genéricas en torno a la bucólica recuerdan la heterogeneidad de la égloga II garcilasiana, tan desconcertante para Herrera, que no quiso ocultar su perplejidad en sus Anotaciones:

Esta egloga es poema Dramático, que tambien se dize ativo, en que no habla el poeta, sino las personas introduzidas, porque Agan es lo mesmo que hacer i representar. Tiene mucha parte de principios medianos, de comedia, tragedia, fabula, coro i elegia. Tambien ái de todos estilos, frases llanas traidas del vulgo, gentil cabeça, yo podrè poco, callar que callaràs; $i$ alto mas que conviene a bucolica, convocarè el infierno, i variacion de versos como en las tragedias.

(Herrera, Anotaciones, 537. El subrayado es mío).

mediocri, cosi la Egloga è di contadini, cioè di bifolci, di pastori, di caprari, e di altre persone rustiche, e aliene dalla vita ciuile», La Poética, p. 497, aunque no la considera escénica, a diferencia de lo que opinan Minturno y el propio Viperano: de hecho, este último se permitió expresar su sorpresa acerca del motivo por que no se hubiera dado antes una atención pormenorizada de los preceptistas acerca de la égloga: cuál podía ser la causa de que los antiguos no hicieran mención alguna al poema bucólico si este tenía su propia esencia, diferenciada de los demás géneros, se preguntaba extrañado. Y sugería que quizá supusieron que podía considerarse incluido en el concepto de comedia, o que carecía del mínimo artificio y que por tanto podía deducirse de los preceptos que se adjudicaban a otros géneros: «Hoc uero etiam mirum videtur, bucolicum poëma fuisse ab illis silentio praetermissum; quod est quidem ex imitatione et carmine, quodque uerisimile est omnium esse uetustissimum; cum ex antiquissimo uiuendi more productum sit, qui pastoritius et agrestis fuit. An forte contineri notione Comoedie putauerunt? Quod nomen late adeo patet, ut omnes fabulas dramaticas significationis suae ambitu comprehendat [...] Sed cur nullam omnino mentionem eius fecere, cum a reliquis generibus uim suam distincta habeat? An quia leui artificio indigeat, et possit ex aliorum praeceptis cognosci?», Giovanni Antonio Viperano, De Poëtica libri tres (Antuerpiae, ex officina Christophori Plantini, 1579).

17. De poeta, p. 163.

18. Picklesimer, op. cit., p. 383.

19. «Iam eiusmodi carminis, quae speciem formamque conficiant, illa eadem quattuor ponenda sunt, quae diximus ad uim uniuersi generis attinere. Huc etiam cantus spectatioque accedunt. Nam pastores ad fistulam canentes introducuntur; quorum carmina in theatris nonnunquam pronuntiantun, De Poeta, pp. 165-166.

20. "Quarum unam epici uendicant; eaque poemata omnia continentur, quibus neque cantu, neque saltatione opus sit», De Poeta, p. 417. 
Y añadió unos significativos versos de Catulo, que no suelen citarse:

En fin, puede decidirse de ella, Quintia formosa est multis, mihi candida, longa,

Recta est; haec ego sic singula confiteor,

Totum illud formosa nego. ${ }^{21}$

Como delatan los versos del cantor de Clodia, el sevillano no tenía en muy buen concepto la égloga II, pues la juzgaba inapropiada en sus partes y desmedida en su conjunto: estaba muy lejos de adivinar en la admirable síntesis de estilos de Garcilaso un adelanto de la más arriesgada poesía experimental de Góngora en sus poemas mayores (y en su prologada polimetría, heredada del Orfeo polizianesco ${ }^{22}$, un anticipo también de la comedia lopeveguesca) ${ }^{23}$. Hay que convenir, además, que no puede afeársele a Garcilaso un ápice de improvisación en el laboratorio sintético (y profético) de recursos literarios de su multiforme égloga II, la primera que compuso. La huella del De Poeta pudo estar en la raíz de su concepción: la bucólica escénica y a vueltas cómica (incluidos todos los consejos para crear lo absurdo y risible, como la locura, fingida o no, así como el hablar consigo mismo ${ }^{24}$, está en perfecta consonancia con la teatralizada aparición de Albanio ${ }^{25}$, y el mismo tratado teórico parece

21. Anotaciones, p. 537. (Transcribo aquí la traducción de Arturo Soler Ruiz: «Quincia resulta hermosa a muchos. Para mí es blanca, alta, derecha. Yo admito que cada uno de sus atractivos es así. Niego que todo ello sea ser hermosa, pues no existe ninguna gracia, ni una pizca de sal en cuerpo tan grande», Catulo, Poemas, Madrid, Gredos, 2000, p. 151).

22. Poliziano pudo ser también un precedente en cuanto al punto de partida genérico (no solo por su polimetría y cauce eglógico-mitológico), al tiempo que una invitación a su mezcla y trangresión. Émile Séris recuerda la mixtura genérica que comprende el Orfeo, una auténtica satura "une macédoine d'éléments divers», además de que en su teoría de los géneros (en su comentario a las Silvas de Estacio y en su introducción a la Ética nicomaquea o Praelectio cui titulus Panepistemon) «il ouvre la classification antique, favorisant l'assimilation de formes modernes et stimulant l'invention de formules inédites. Il prône clairement le genre mixte qu'il s'agisse du mode d'énonciation, du style ou de la forme rythmique. Toutefois, la réflexion du poéticien ne me paraît pas aller jusqu'à remettre en cause l'idée même de genre. S'il y a transgression des catégories (la limite entre poésie et prose) et même subversion de certaines d'entre elles (l'épopée), pas un instant leur suppression n'est envisagée. Au contraire, Politien est l'un des tout premiers humanistes à proposer une théorie des genres complète et construite», "Ange Politien: mélange des genres, genre mixte ou refus de généricité?», en Paloma Bravo, Cécile Iglesias et Giuseppe Sangirardi (eds.), La Renaissance des genres. Pratiques et théories des genres littéraires entre Italie et Espagne ( $X V^{\star}-X V I I^{e}$ siècles), Dijon, Éditions Universitaires de Dijon, 2012, pp. 49-63.

23. A pesar de que Herrera conocía el texto de Minturno, parece más directamente influido por las Lucullianae Quaestiones de Maranta, como ha recordado María José Vega (El secreto artificio: qualitas sonorum, maronolatría y tradición pontaniana en la poética del Renacimiento, Cáceres, CSIC, 1992, p. 230). El texto de Maranta, por otro lado, está poderosamente influido por el de Minturno, y situado voluntariamente en una generación posterior, por lo que su lamento por la ruina de Italia carece de valor cronológico, pues no es más que un reconocimiento del modelo tratadístico inaugurado por su predecesor.

24. «Iam subabsurda, quae, ut Fabius [Quintiliano] docet, constant stultissimi imitatione, et quae, nisi fingantur, stulta sunt, non parum oblectant», p. 345.

25. Cabría preguntarse qué posibilidades dramáticas advirtieron en su día los poetas en el frustrado suicidio de Albanio, a quien Garcilaso salvó de arrojarse al precipicio (inspirándose 
ser el telón de fondo preceptivo para la creación del complejo marco pastoril que permitiría la introducción en su seno del discurso heroico sobre la Casa de Alba. He aquí un texto preceptivo, el único, que promueve la heterogeneidad en la égloga. No se olvide que Minturno practicó una suerte, distinta, eso sí, de mezcla heroico-pastoril, en algunos de sus poemas laudatorios ${ }^{26}$. Como fuere, en la égloga II de Garcilaso no hay fusión de esos elementos polarizados (como se daría en el caso del epilio), si no su clara yuxtaposición, lo que deja al descubierto el origen conceptual de su dispositio ${ }^{27}$.

El De Poeta pudo contribuir también a dar preeminencia al género eglógico en la obra de Garcilaso y a autorizar su dignidad entre los demás géneros poéticos neoclásicos. La prolongada atención que Minturno le dedica, así como los esfuerzos por conferirle altura desde un sesgo preceptivo, son una absoluta novedad, no solo en los tiempos en que se escribió la obra, sino tres decenios después, cuando la obra se publicó (1559). Es Sannazaro la voz autorizada que habla sobre el género en que tanto descolló: así lo sanciona Gravina al ir concluyendo la conversación en el libro II, cuando se dirige a Syncerus para agradecerle su intervención acerca de un género en el que reina de forma

lejanamente en las palomas amorosas que disuaden de morir al Carino sannazariano) gracias al golpe de viento que lo tumba de espaldas, que en el drama pastoril -tan lírico como representable- de Torquato Tasso adquirió la forma de unos arbustos que frenan la caída desesperada de Aminta (en ambos casos, hay que recordar, la escena no es presenciada por el espectador sino que se narra). No olvidemos que el pastor suicida que Garcilaso toma de Juan del Encina se convertirá en todo leitmotiv de la pastoral representable italiana.

26. Cf. R. Béhar, «Le De adventu Caroli imperatoris in Italiam (ca. 1536) de Minturno: la célébration heróïque et mythique de Charles Quint», en M. Jean-Louis Perrin et N. Catellani-Dufrêne (eds.), La lyre et la pourpre. Poésie latine et politique de l'Antiquité tardive à la Renaissance, Rennes, Presses Universitaires de Rennes, 2012, pp. 117-132.

27. Los intentos por encontrar la unidad escondida en la disposición de la Égloga II han sido muy variados: quizá de entre los más recientes el más sugerente sea el de Roland Béhar («Virgilio, san Agustín y el problema del poema heroico cristiano (1520-1530)», Criticón, no 107, 2009, pp. 57-92), quien, horadando en las fuentes sannazarianas, puestas al descubierto en su día por Mele, interpreta que Garcilaso echó mano del artificio de la ekphrasis profética en el De Partu Virginis por medio de una serie de citas textuales en lugares clave para legitimar la presencia de la profecía (las correspondencias se dan al comienzo y al final de la misma), reconociendo así tácitamente la deuda que en esta reflexión tenía con el autor de la Arcadia, tan ampliamente imitada, por otra parte, en el pasaje bucólico, puesto en boca de Carino, de la misma égloga. Véase en este mismo volumen el interesante análisis de la Égloga II por parte de Antonio Gargano, cuya visión amplía y complementa las sugerencias de Béhar. Ambos acercamientos parten del concepto de ekphrasis profética propia del texto épico (cuya fuente es el texto épico cristiano de Sannazaro, y también el vulgar de Ariosto); quizá faltaba buscar una explicación a la introducción en un texto bucólico activo (o dramático) de un recurso tan típicamente heroico. Si bien, como se ha visto, el De Poeta ofrece, desde la preceptiva, una justificación a esa yuxtaposición de elementos, cabría recordar también el papel que sin duda hubo de cumplir en la praxis literaria el modelo polizianesco del Orfeo, que inaugura en las puertas del XVI la tradición de la égloga mitológica (presente en la Égloga II en su poliestrofismo y en la imitación compuesta), pues contiene, en los manuscritos M y S, una oda latina en alabanza del Cardenal Gonzaga, con el vaticinio de su pontificado (véase A. Tissoni. L'Orfeo del Poliziano con il testo critico dell'orginale e delle sucessive forme teatrali, Roma, Editrice Antenore, 2000). 
suprema y en el que parece confortablemente instalado, como un rey en su trono $^{28}$. En su discurso, jalonado de múltiples citas de las églogas virgilianas como ejemplos de división de partes, estructura, voces alternas, símiles, amplificaciones, similitudes, comparaciones, analogías, metáforas, hipérboles, estilos y ritmos poéticos, Minturno (si bien por boca de Sannazaro) hilvana un compendio de Landino ${ }^{29}$ y la terminología de las defensas de la poesía del primer humanismo, con sus alusiones a los velos que esconden la verdad ${ }^{30}$. Este concepto de la égloga como quintaesencia de la tendencia alegórica propia de

28. Fue Sannazaro el primero que cantó bucólicas en las propias costas ("Quandoquidem nostra cecinisti primus in acta», dice exactamente Minturno/Gravina, citando calladamente el verso 45 de la segunda piscatoria de Sannazaro) y quien con la máxima excelencia trasladó esa poesía de los bosques a la costa, de los campos al mar y de los rebaños a los peces. También fue él quien supo imitar tanto la simplicidad de Teócrito como la gravedad de Virgilio. «Omnes cum id sibi placere dixissent, tum Grauina, uidete, inquit, quam liberaliter, et quam oppipare nos excipiat Syncerus. Cui non satis erat nos doctissimis disputationibus erudire, nisi etiam accubatione epulari oblectaret. Sed de poemate bucolico cum diceres Syncere, in eo regnare te plane ostendisti. Ac iure uideris in eiusmodi carmine, quo praeclara quaedam scripsisti, tanquam in tuo regno uersari. Quandoquidem nostra cecinisti primus in acta, et summa cum laude hanc poesim a syluis ad littora, ab agris ad mare, a pecore ad pisces transtulisti. Quippe quem unum omnes existimamus et simplicitatem Theocriti, et Virgilii grauitatem effinxisse». De Poeta, p. 169.

29. Razonaba Landino que a pesar de que Virgilio fue realmente excelente en el bucolismo y lo perfeccionó en todas sus cadencias de manera que no cedió nada a quien se proponía imitar (Teócrito), concertó algunas cosas más altas de su invención, a la manera de los poetas: sin despegarse del personaje rústico, escondió no obstante una mucho más alta sensibilidad bajo esta más baja, empleando la obra en dos niveles, al dedicarse tanto al tema externo cuanto al escondido, y -ańade Landino- a quien considerara esto un defecto, podría acusársele de ignorar la verdadera naturaleza de la poesía. "Quod qüidem cum praestiterit ac per omnes numeros ita absolverit, ut ei quem sibi imitandum proposuerat nusquam cedat, tamen, quod poetarum est, eodem figmento maiora quedam contegit: ut quanvis a persona pastorali non discedat, tamen alium sensum longe excellentiorem sub illo vulgari abscondit, ut opus duplici argumento et illi qui in promptu est inserviat et illum qui latet perficiat : quam rem siqui qui vitio illi vertant, ii quid proprium poetarum sid ignorare convincentur». Roberto Cardini, La critica del Landino, Firenze, Sanzoni, 1973, pp. 213-214. Sobre este mismo fragmento llamó la atención Fred J. Nichols, «Development of Neo-Latin theory of the Pastoral in the Sixteenth Century», Humanistica Lovaniensia, vol. 18, 1969, pp. 102-103. Vilà también se ha referido a él en «Lírica laudatoria y retórica epideíctica en el Renacimiento", en M. J. Vega y L. Vilà (eds.), La teoría de la épica en el siglo XVI, Vigo, Editorial Academia del Hispanismo, 2010, p. 190, n. 45.

30. Petrarca y Boccaccio definieron la poesía como la descripción a través de un velo (sub velamento) o la representación indirecta a través de imágenes (oblicuis figurationibus). La obligación del poeta era, según Petrarca, inventar, quiere esto decir, componer y embellecer; presentar en colores artísticos y cubrir con el velo de una ficción amena la verdad de lo insignificante o lo natural. La verdad, cuando se revelaba, era tanto más agradable cuanto difícil había sido descubrirla. "Officium eius (poetae) est fingere, id est componere atque ornare et veritatem rerum, vel mortalium, vel naturalium, vel quarumlibet aliarum artificiosis adumbrare coloribus, et velo amoenae fictionis ob nubere, quo dimito veritas eluscescet, eo gratior, quo difficilior sit quaesitu» (Epistolae seniles, XII, 2). Cf. «Et quoniam ex fervore hoc ingeniorum vires acuente atque illustrante nil nisi artificiatum procedit ars, ut plurimum vocitata poesis est [...] mera poesis est, quidquid sub velamento componitur et exponitur exquisite» (Boccaccio, Genealogia Deorum Gentilium, XIV, 7). 
la más alta poesía podría hallarse a su vez en el trasfondo teórico del alegorismo autobiográfico de la égloga III ${ }^{31}$.

Minturno/Syncerus opina que Virgilio es un poeta magnífico, puesto que cuando introduce personajes bajos que hablan de manera simple y rústica encaja en su lúdica caracterización cierta seriedad escondida; por eso embellece su obra, que es simple y ligera, porque mientras por un lado nunca quita el velo al personaje que retrata, por otro lado las partes subyacentes aportan una técnica más elegante, ingeniosamente elaborada de forma que los velos internos permanecen escondidos en los velos externos del poema. Virgilio alaba a Augusto y Pollio, llora la muerte de César, lamenta la pérdida de sus tierras y se alegra de recuperarlas, aunque parezca que está haciendo otra cosa. Esta es la verdadera costumbre de los poetas, esconder la verdad en falsedades y envolver las cuestiones graves en otras lúdicas. En cualquier caso, tampoco en las tres églogas que se consideran menos bucólicas rechazó Virgilio la máscara pastoril. Precisa algo más adelante el Syncerus minturniano que Virgilio fue el primero en mostrar la posibilidad de que la poesía bucólica incluyera cosas profundamente ajenas al medio bucólico, de tal forma que no aparecieran disminuidas (i.e. por asociación a su «bajo» género). En cualquier caso, añade, nunca llevó a cabo nada parecido sin gran precaución ${ }^{32}$.

31. Acerca del posible influjo de Minturno en este fragmento autobiográfico de la égloga III de Garcilaso, véase Fosalba, op. cit., 2009. Citando y parafraseando aquí la interpretación del pasaje por parte de Rivers, se observa que «...el dolor de Nemoroso está oculto tras múltiples velos. Lo que oímos es literalmente el eco de su voz», cuando la sola palabra «Elisa» resuena desde el monte hasta el río; este eco tiene lugar en el epitafio en que la diosa de los bosques recoge la voz de la difunta Elisa al grabar sus palabras en la corteza de un árbol. «Y la misma diosa no es más que una figura secundaria ('apartada algún tanto')» pero inmersa de lleno en el tapiz del que se describe en primer lugar a la ninfa muerta. En cada una de las tres secuencias mitológicas el lamento del afligido amante, representado sin más subterfugios, de forma directa, era una suerte de culminación de cada narración trágica que dominaba los últimos versos de la secuencia. En cambio, «Nise, al rechazar con deliberación de los passados casos la memoria (194), muestra una secuencia más inmediata, geográfica y cronológicamente, tanto para el poeta como para el lector», pero esta historia situada en las inmediaciones del Tajo, junto a la señorial ciudad de Toledo, retrocede «al pasado al convertirse en el cuarto tapiz colgado en una galería de antiguos exempla. Y, como se ha señalado, el duelo de Nemoroso retrocede de igual forma en la distancia, al convertirse en una cita dentro de una cita dentro de una pintura...», E.L. Rivers, "Paradoja pastoril del arte natural», en La poesía de Garcilaso, Barcelona, Ariel, 1981, pp. 300-301. De esta forma tan gráfica, Garcilaso eleva a la categoría de mito una historia amorosa supuestamente personal, al incluirla como una pieza más de la serie de bordados cromáticos y decorativos que embellecen su égloga.

32. "His ducibus a recta scribendi via nemo mehercule uestrum aberrauerit. Nam in qua materia atque in qua ratione dicendi uersetur hoc genus, quis ignoret? Vtraque humilis est, et attenuata. Et uero quae pastoribus conueniat, rustica enim simplicitate contenta est, quae nec acutas, granesque sententias, nec uerborum ornamenta conquirit. Ac septem a Virgilio Eclogas (sic ille appellat quae Theocritus Idyllia) ita scripta reperies. Nisi reprehendendum putas, quod fabula pastorali maiora quaedam contexerit. Et quae ut dicant, pastores inducuntur, ad alia intellexerit esse transferenda. Mihi uero ille uel hoc praecipue mirabilis uidetur, quod cum agrestes humilesque personas, quae nibil non rusticum simplexque loquantur, introducat, lusu illo grauia quaedam abdite comprehendit, opusque per se nudum ac tenue sic exornat, ut cum exteriorem habitum et personae conuenientem 
Esos velos que ocultan la verdadera identidad del poeta adquieren, en la égloga III de Garcilaso, el gráfico aspecto de las varias capas (tapiz, corteza, epitafio, voz de Elisa, eco de la voz de Nemoroso) que cubren la experiencia supuestamente autobiográfica de la pérdida del ser amado, transformada en arte dentro del arte (o en esa apariencia lúdica de las cosas graves). Rivers intuyó hace muchos años «implicaciones teóricas» en este fragmento de la égloga III, que le recordaban la síntesis de Escalígero ${ }^{33}$; motivos geográficos y cronológicos de peso aconsejan, en cambio, dirigir la mirada a las pormenorizadas páginas consagradas a la bucólica del precoz tratado de Minturno.

Pero hay otros aspectos del De Poeta que pueden haber influido en las églogas garcilasianas: en sus páginas se da una sutil omnipresencia, en casi todo momento callada, pero siempre latente, de la poesía contemporánea en vulgar. De ahí las alusiones a Petrarca del libro V, cuando se recuerda que todo lo que se ha mencionado sobre la poesía mélica de los antiguos es lo que Minturno acostumbraba a decir sobre los cantos toscanos que ahora se entonan, y a continuación se asevera que no hay casi ningún género de los que existieron en la lírica antigua que no se encuentre en los suavísimos poemas de Petrarca ${ }^{34}$.

Finalmente, todavía en el libro V, Carbo añade unas palabras que merecen gran atención: le dice a Scortianus (Luzio Camillo Scorziano) que su amigo (por Minturno) merece ser alabado por observar los preceptos tan bellamente (hay que entender en su obra poética en vulgar). No solo eso: también asevera que por todos los matices que añadió Minturno merece la gratitud de todos los poetas que escribieron poemas en ritmos toscanos (y aquí parece claro que alude a su labor como preceptista). A continuación afirma que Petrarca merece gratitud en cuanto precursor de este método de escritura, y que la principal razón de agradecimiento es que hizo fácil escribir sin que los demás poetas tuvieran que cantar a ciegas, y sin olvidar dar a conocer las destrezas de los modos antiguos de cantar ${ }^{35}$.

nunquam exuat, interiorem induat politiorem in modum, atque cum in id quod apparet, incumbat id quod latet, probe conficiat. Augustum enim, Pollionemque laudat, Caesaris interitum deplorat, queritur se amisisse agrum, recepisse laetatur, cum aliud agere uideatur. Is poetarum sane mos est, ut fictis uera occulte, ludo seria complectantur. [...] Itaque primus docuit quae a bucolica ratione putantur abhorrere, quam probe attingi possint, quo minus dedecere uideantur. Nec uero eiusmodi quidquam sine praemunitione aggreditun, De Poeta, pp. 162-163.

33. Rivers, op. cit., p. 307.

34. «Hoc loco Scortianus, cum finem dicendi Carbo facturus esse uideretur, attendenti mihi, et cogitatione complectenti, illum intuens inquit, quae de melica scribendi ratione disserebas, in mentem id uenit, quod de canticis, quibus haec etas utitur, Hetruscis dicere solet Minturnus noster, ut pote qui multa eiusmodi conscripsit, nullum propemodum apud ueteres lyricos genus extitisse, quod in suauissimis Petrarchae cantibus deprehendi non possit», De Poeta, cit., p. 399. Origen, sin duda, de la obra que habría desarrollado a continuación sobre la poética toscana: L'Arte poetica, Venetia, Gio. Andrea Valuassori, 1564 (reedición anastática Wilhem Fink Verlag, München, 1971).

35. "Ac merito laudandus esse mihi quidem uidetur amicus ille tuus, qui haec tam belle obseruanit, et uere dignus est, cui gratiam habeant cum omnium manes, qui numeris Hetruscis poemata scripserunt, tum Petrarcae facile principis in ea ratione scribendi, quod eos non temere cecinisse, sed ueterum modos in canendo adhibuisse docuerit. Hoc itaque additamento perfectum adeo, completumque esse credo id omne, quod erat de melico genere tractandum, ut nibil sane reliquum existimem, 
Es decir que Petrarca abrió el camino de una docta poesía vulgar, a la que Minturno añadió matices (desde su poesía vulgar y desde sus lecciones teóricas sobre poesía en vulgar). Esta presencia latente de la poesía en vulgar reaparece a comienzos del Libro VI, cuando Summontius insiste a Syncerus en que aclare cómo se define frente a Bembo, cuando le interpela e inquiere por qué está tan callado respecto a sí mismo y al maestro veneciano, que es tan admirado en Roma. Los genios de ambos se han hecho famosos por todo el gran teatro de Italia -o aún mejor, en el mundo entero. El maravilloso esplendor de su sabiduría brilla más allá de la admiración de todo el mundo. ¿Qué es lo que es diferente en él y Bembo con respecto a la escritura? Primero por su obra latina, después por la vernacular, gozan ambos de la más alta estima. La diligencia de Bembo ha sido especialmente aprobada, así como su cuidadosa elección de las palabras. Al verse despreciado por no ser toscano, Bembo se sumergió por completo en la lengua toscana. Todos alaban la agradable naturaleza de Sannazaro, su poder e interior de singular dignidad. Si Bembo perseguía un tipo de latín cultivado, controlado y enmendado, Sannazaro siguió, por el contrario, lo que era espléndido, magnífico, bello y fértil, lo que llena los oídos y no separa lo elevado de lo agradable, lo leve de lo grave; a saber, podría añadirse: proporcionó una admirable ductilidad a la poesía contemporánea ${ }^{36}$.

La respuesta de Syncerus no se hace esperar: sobre Bembo nada es tan superlativo que no se le pueda atribuir. Sobre sí mismo, en cambio, no es cosa suya decirlo, primero porque hablar sobre sí mismo le duele, y porque da por supuesto que nadie le conoce (en un alarde de modestia con que Minturno pone de manifiesto no solo su preferencia intelectual, sino también humana, por Sannazaro). Por eso considera que no puede juzgar con propiedad acerca de lo que se le pide. Pero viendo que se le compara con el más excelente de los hombres, se decide a mencionar una falta que se les achaca a ambos. Como él, Bembo se atormenta con notable ansiedad por si se encuentra algo cuestionable en su discurso. En cambio, él es más vigilante ante la necesidad de excluir todo lo impuro y redundante. Él es más ambicioso en la observación de los ritmos, en la disposición de los sonidos y las palabras ${ }^{37}$.

quod praeterea requiraturn, De Poeta, p. 400.

36. «Hoc loco Summontius, de te uero, inquit, quid est quod Syncere taceas, ac de Petro Bembo, quem unum Roma in primis admiratur. Vtriusque quidem sane ingenium tota Italia, quasi maximo theatro, ac potius toto terrarum orbe, ubi doctrinae splendor uel tenuis eluceat, magna cum omnium admiratione spectatum est; ac tecum ille unus hominum sermonibus in comparationem tanquam in contentionis iudicium uocatur. Quid autem ita dispar ut ille, ac tu in scribendo? Quando enim uterque tum Latina, tum hac, qua uulgo loquimur, lingua, multa, quae summo habentur in pretio, conscripserit, in hac alterius quidem industria maxime probatur, accuratusque uerborum delectus. Cum prorsus, quod Hetruscum non sit, aspernatus, in eam se totum induisse locutionem ille videatur. Naturae autem suauitatem in te, copiamque et perspicuitatem cum singulari dignitate coniunctam, nemo est qui non mirum in modum laudet. Latianae etiam cultum, pressumque ille genus et emendatum secutus est. Tu nero quod splendidum esset, quod manificum, quod suaue, quod uber, quod aures impleret, quod nec iucunditate granditatem, nec grauitate facilitatem excluderet,, De Poeta, p. 440.

37. «De Bembo quidem, ille inquit, nihil sane tam praestans est, quod praedicare non possim. De me uero meum non est profecto dicere, tum quia memet mei poenitet, tum quod nemo se ipsum nouit, 
Este ficticio intercambio verbal resulta muy revelador de lo que pudo significar el De Poeta en el umbral de los ańos treinta: una toma de postura napolitana ante las aportaciones de Bembo en las Prose della volgar lingua (1525), planteada, sin embargo, lejos de la enmienda parcial o total, como un complemento. Si Bembo había mejorado la lengua poética ofreciendo fórmulas, soluciones léxicas y una koiné poética derivada de la labor limae petrarquesca, Minturno, con el De Poeta, pretendía destacar cuál era en ese mismo contexto literario (y por tanto también cronológico) la aportación meridional: el rescate de lo más alto de la poesía clásica y virgiliana, del ritmo de los versos, de su admirable fluencia y capacidad representacional, a través del sonido. La escuela pontaniana es la contribución fundamental de Nápoles que la poesía en vulgar no debería olvidar jamás, nos viene a decir el de Traetto con su diálogo: la observación con lupa de los avances técnicos de Virgilio, gracias a las ideas heredadas de Trapezuntius y la retórica ciceroniana, retomadas ahora también a través del Actius y multiplicadas en el tratado de Minturno, donde esas consideraciones y ejemplos se amplían y sistematizan con extraordinario pormenor ${ }^{38}$. Téngase en cuenta que en el De Poeta apenas se dispensa atención a la métrica antigua; no interesa, se prefiere parafrasear con persistencia a Cicerón ${ }^{39}$, precisamente, a buen seguro, por la orientación tácita de toda esta preceptiva neoclásica a su aplicación en la poesía contemporánea. Por eso solo se observa con atención el hexámetro, que es del que Trissino establece que ha derivado el endecasílabo; de hecho, el tratamiento que se da de la voluptas aurium o placer de los oídos serviría tanto para la prosa como el verso. Difieren en muy poco, nos viene a decir Minturno, y quizá por esa razón llama prosa 'n rima a sus versos italianos en uno de los primeros sonetos de sus Rime.

La fuerte vocación didáctica de Minturno pormenoriza los ejemplos, sobre todo virgilianos ${ }^{40}$, mucho más abundantemente que otras poéticas, en abierto

nec recte sit ut de se statuat quisquam. Sed quoniam cum summo uiro illo comparatione coniungor, non dissimulabo quod utrique uitio datur, me non secus, atque eundem illum nimia cura torqueri, ne quid deprehendatur obsoleti in oratione. Verum attentius illum incumbere, ne quid purum non sit, ne quid redundet; me numeros, sonantiumque uerborum colligationem ambitiousius obseruare. Videtis igitur nos pauci quam inter nos multa dissimilitudine distemus, quam cuique aliqua cum laude proprium sit et peculiare, ut hinc plane perspectum haberi queat, si quot sunt poetae, quotque fuerunt, omnes inter ipsos conferre uelimus, fore, ut non plura ingenia poetarum, quam in poesi genera scribendi appareant», De Poeta, p. 440.

38. La exposición del sonus en el De Poeta se distribuye en los siguientes puntos: el sonido de las letras y las sílabas en la dicción poética; los concursos y más específicamente, la continuatio verborum o concursos de la juntura de las palabras; la necesaria adaptación del sonido del verso a la materia y al estilo (con ejemplos virgilianos de gradaciones sonoras desde lo más áspero y duro hasta lo más tenue y suave); el concentus, aplicado a las repeticiones de elementos o letras, la descripción de su tipología y efectos; la muestra de funciones y efectos del sonido verbal en la poesía y en especial, de las aliteraciones. Véase la síntesis de María José Vega en op. cit., esp. p. 60.

39. Véase al respecto Carlos de Miguel Mora, «La doctrina métrica en el De poeta de Minturno», en J. Luque Moreno y P. Díaz Díaz (eds.), Estudios de métrica latina, Granada, Servicio de Publicaciones de la Universidad de Granada, 1999, pp. 617-632.

40. Su propósito es impulsar a los jóvenes a escribir bien, asevera en las primeras páginas del libro II: «Ut inflammarem adolescentes ad bene scribendum», De Poeta, p. 85. 
y revelador contraste con la poética de Trissino, concentrada, esta última, en proponer soluciones métricas en sus primeras cuatro partes, mientras ofrece una síntesis muy breve de las ideas fundamentales sobre tragedia y épica en la quinta y sexta. En la carta dedicatoria a Girolamo Ruscelli, el de Traetto explicita, además, que no se propuso ser breve y brillante, a costa de ser menos claro y pedagógico, por huir de la prolijidad (como sí hizo Girolamo Vida en su De arte poetica $)^{41}$. Recuérdense a este propósito las lecciones acerca de poética que impartió siendo muy joven en Pisa, en una suplencia de un año durante el invierno de 1520, cuando Mariano Tucci dejó vacante su cátedra ${ }^{42}$ : su irreprimible vocación didáctica es la que lo aboca a tratar con tantísimo detalle desde la disposición de las unidades de sonido más pequeñas hasta la combinación de las palabras, convencido de que en la articulación con cuidado de orfebre de todos estos elementos, desde el más pequeño hasta el más amplio, radica la ductilidad del ritmo del verso.

El De Poeta ponía la atención en todo lo que todavía no se había aplicado del mundo de la poesía grecolatina a la poesía vulgar desde que la labor limae de Bembo popularizó el petrarquismo: ¿qué se echaba en falta en estos momentos clave, fundacionales? Nada menos que resucitar el resto de géneros poéticos neoclásicos que aún no habían experimentado la vulgarización. De entre ellos, el género bucólico recibe por primera vez en la historia de la preceptiva una atención tan pormenorizada, dilatada y compleja que no tiene nada que envidiar a la épica, de la que además forma parte. Así no extrańa que Garcilaso pusiera lo mejor de sí mismo en sus tres églogas. ¿Qué decir sobre la extraordinaria fluencia, sobre la variedad de ritmos, la adecuación sonora a la representación de la materia, que Garcilaso consigue insuflar a los endecasílabos de su égloga III? A juzgar por las enseñanzas del De Poeta y por los resultados alcanzados en las églogas del toledano, resulta inevitable concluir que la obra de Garcilaso es una de las mejores puestas en práctica del programa poético planteado por Minturno en su De Poeta. Como él mismo explica en el soneto 24 a dońa Maria de Cardona, hasta ahora el cauce se encontraba seco, pero gracias a la guía de tan buenos compañeros de viaje podrá desbrozarlo para que en adelante lo surquen sin obstáculos las fértiles aguas del río patrio:

41. "Quae uero praecipiebantur, ut essent planiora, cum neque laboris quicquam fugiendum, neque ulli operae parcendum mihi esse censuissem, permulta haec exemplorum copia illustranda existimaui. Quanquam enim, cum ad haec ipsa tam distincte, tam partite, aut potius tam particulatim attingenda descenderem, ab ea fortasse uidebar discedere, in qua granitate stare potuissem; malui tamen id agere, ut poeticae artis imperiti, ac rudes de ea praecepta planissime intelligerent, quam meae consulere dignitati; si dignitatem suam is potius tuetur, plusque meretur laudis, qui in docendo ne maiestatem dicendi ponat, multa negligit, quibus, quod praecipitur, luculentius explaneretur, quam cuius oratio redundat, nibilque praetermittit, quod ad rem, de qua agitur, ante oculos ponendam conducere nideatum, De Poeta, dedicatoria a Ruscelli, sin paginación.

42. P. G. Ricci, «Antonio da Traetto, cioè il Minturno. Da Rinascimento», Rinascimento, no 2, 1956, pp. 363-367. 
Illustre honor del nombre de Cardona, décima moradora de Parnaso, a Tansillo, a Minturno, al culto Tasso sujeto noble de inmortal corona, si en medio del camino no abandona la fuerza y el espírtu a vuestro Laso, por vos me llevará mi fatigado paso a la cumbre difícil d'Elicona.

Podré llevar entonces sin trabajo, con dulce son qu'el curso al agua enfrena, por un camino hasta agora enjuto, el patrio, celebrado y rico Tajo, que del valor de su luciente arena a vuestro nombre pague el gran tributo. 
